\title{
Emergency workers' experiences of the use of section 136 of the Mental Health Act 1983: interpretative phenomenological investigation - ERRATUM
}

Mirella Genziani, Steve Gillard, Lana Samuels, Mary Chambers

BJPsych Bulletin (2022) 46, 258, doi:10.1192/bjb.2020.141

(c) The Author(s), 2020. This is an Open Access article, distributed under the terms of the Creative Commons Attribution licence (http://creativecommons.org/ licenses/by/4.0/), which permits unrestricted re-use, distribution, and reproduction in any medium, provided the original work is properly cited.

https://doi.org/10.1192/bjb.2020.21, Published online by the Royal College of Psychiatrists, 17 March 2020

In the original published article, the country name was missing from a co-author's affiliation. This has now been corrected.

\section{Reference}

Genziani M, Gillard S, Samuels L and Chambers M. Emergency workers' experiences of the use of section 136 of the Mental Health Act 1983: interpretative phenomenological investigation. BJPsych Bull 2020; 44(6): 250-54. Available from: https://doi.org/10.1192/bjb.2020.21. 